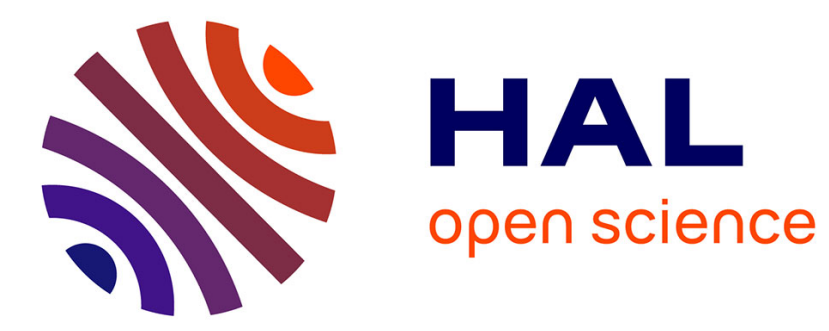

\title{
Spatio-temporal heterogeneity effects on seedling growth and establishment in four Quercus species
}

\author{
González-Rodríguez, Villar, Casado, Suárez-Bonnet, José Quero, Rafael \\ Navarro-Cerrillo
}

\section{- To cite this version: \\ González-Rodríguez, Villar, Casado, Suárez-Bonnet, José Quero, et al.. Spatio-temporal heterogeneity effects on seedling growth and establishment in four Quercus species. Annals of Forest Science, 2011, 68 (7), pp.1217-1232. 10.1007/s13595-011-0069-z . hal-00930803}

\section{HAL Id: hal-00930803 https://hal.science/hal-00930803}

Submitted on 1 Jan 2011

HAL is a multi-disciplinary open access archive for the deposit and dissemination of scientific research documents, whether they are published or not. The documents may come from teaching and research institutions in France or abroad, or from public or private research centers.
L'archive ouverte pluridisciplinaire HAL, est destinée au dépôt et à la diffusion de documents scientifiques de niveau recherche, publiés ou non, émanant des établissements d'enseignement et de recherche français ou étrangers, des laboratoires publics ou privés. 


\title{
Spatio-temporal heterogeneity effects on seedling growth and establishment in four Quercus species
}

\author{
Victoria González-Rodríguez • Rafael Villar • \\ Raquel Casado • Elena Suárez-Bonnet • \\ José Luis Quero • Rafael M. Navarro-Cerrillo
}

Received: 17 January 2011 / Accepted: 20 April 2011 / Published online: 23 June 2011

(C) INRA and Springer Science+Business Media B.V. 2011

\begin{abstract}
- Introduction The great spatial and temporal heterogeneity of Mediterranean ecosystems can influence establishment success in woody species, whose natural regeneration occurs to a very small extent. In this work, the effect of the spatial pattern of environmental variables (light availability, soil moisture and herbaceous production) on seedling emergence, growth, survival and establishment success was examined by using a spatially explicit approach.

- Methods Seeds of four Quercus species differing in leaf longevity (Quercus ilex, Quercus suber, Quercus faginea and Quercus pyrenaica) were sown in two plots located in a holm oak forest (southern Spain). The spatial pattern of the studied variables was examined by Spatial Analysis by Distance Indices.

- Results All environmental variables exhibited an aggregated spatial pattern. There was no clear spatial association between the environmental variables and emergence and survival. Only soil moisture during the dry season was
\end{abstract}

Handling Editor: Douglass Jacobs

V. González-Rodríguez $\cdot$ R. Villar $(\bowtie) \cdot$ R. Casado $\cdot$

E. Suárez-Bonnet

Área de Ecología, Universidad de Córdoba,

Edificio Celestino Mutis, Campus de Rabanales,

14071 Córdoba, Spain

e-mail: bv1vimor@uco.es

\section{J. L. Quero}

Área de Biodiversidad y Conservación, Departamento de Biología

y Geología, Universidad Rey Juan Carlos, ESCET,

C/Tulipán s/n

28933 Móstoles, Spain

R. M. Navarro-Cerrillo

Departamento de Ingeniería Forestal, Universidad de Córdoba, Edificio Leonardo da Vinci, Campus de Rabanales,

14071 Córdoba, Spain spatially associated with the establishment success of all the species. Species also differed in survival and establishment success, with evergreens having higher percentages than deciduous. No aggregated spatial pattern for growth and morphological traits was apparent, these being more dependent on seed mass than on environmental factors. Identifying which microsites facilitate regeneration may provide useful hints with a view in focusing restoration endeavours on microenvironments with high survival percentage.

Keywords Oak $\cdot$ Regeneration $\cdot$ Seedling performance . SADIE $\cdot$ Survival $\cdot$ Variability

\section{Introduction}

Natural regeneration in Mediterranean vegetation is heavily limited at all stages (Jordano et al. 2008), but particularly in seedlings, which are highly sensitive to their microenvironmental conditions (Urbieta et al. 2008a). The availability of major resources including light, water and nutrients for plants can change within a few metres (Gallardo 2003; Gómez et al. 2004; Quero et al. 2011). Also, these environmental factors exhibit complex mutual relationships (Sack and Grubb 2002; Gallardo 2003) and can vary widely in space and time, affecting ecosystem structure and composition (Terradas 2001; Maestre 2006). Thus, open forest areas possess a light availability that influences not only abiotic resources, such as nutrients or soil moisture (Pérez-Ramos et al. 2010), but also the structure and composition of the herbaceous layer (Milton 1995). Herbaceous abundance can either diminish seedling survival through competition for water (Rey Benayas et al. 2005) or increase it by reducing evaporation and alleviating the effects of high temperatures (Gómez-Aparicio et al. 2005b). 
In addition, the spatial structure of seedling recruitment may be governed not only by resource availability but also by factors involved in the earliest regeneration stages such as seed rain and dispersal (Gómez et al. 2004; García and Houle 2005).

Therefore, the spatial distribution of environmental variables, which usually takes the form of gradients or patches, is usually of a non-random nature and promotes the formation of heterogeneous microsites to which plants respond differently (Jurena and Archer 2003), thereby facilitating coexistence between species (Beckage and Clark 2003).

The spatial structure of environmental variables is also time-dependent. The significance of temporal variability in the resources for establishment success has been the subject of many studies (Paynter et al. 1998; Castro et al. 2004; Gómez-Aparicio et al. 2005a), especially under Mediterranean and semi-arid climates, where water is a highly restrictive resource (Milton 1995). Thus, Quero et al. (2011) found the spatial structure of plant survival to vary between years with a different precipitation. In wet years, there is a high microsite availability, and therefore, survival is high, and it is not aggregated along the space; on the other hand, in dry years, there is no aggregated survival along the space due to the unsuitability of the microsites. Aggregated survival only emerges under intermediate scenarios because the spatial structure of environmental conditions (i.e. patches with greater water availability) influences the spatial survival pattern. Therefore, experimental designs and statistical analyses should consider the above-described spatial and temporal heterogeneity (Legendre 1993) in order to assess accurately the influence of some key factors affecting early recruitment stages. Although an increasing number of spatially explicit experimental designs is being used to examine spatial patterns for recruitmentrelated variables (Maestre et al. 2003; García and Houle 2005; Quero et al. 2011), few authors have applied them simultaneously to several phylogenetically related species differing in leaf habit (evergreens vs deciduous) and leaf longevity. Leaf longevity is a key variable of the leaf economics spectrum (Wright et al. 2004) related to the resource acquisition versus resource conservation strategies, and it could also explain the different response of species with environmental factors (RuizRobleto and Villar 2005).

Moreover, no study appears to have so far been conducted to establish the spatial patterns for morphological- and growthrelated variables in seedlings (see Laliberté et al. 2008), which might have an impact on plant establishment. Seedling growth rates are very often influenced by environmental factors (Poorter 2001; Villar et al. 2008); therefore, changes in such factors along spatial and temporal gradients might lead to the presence of areas with bigger or faster growing seedlings. In addition to environmental factors, some intrinsic traits such as seed mass determines early seedling performance (González-Rodríguez et al. 2010, 2011; Pérez-Ramos et al. 2010), especially on large-seeded species growing in unfavourable environments (Leishman and Westoby 1994). Experiments that evaluate seedling growth have been typically carried out under controlled conditions, and field experiments often limit growth measures only to seedling height (Beckage and Clark 2003; Laliberté et al. 2008). Moreover, those trials do not give any information about leaf biomass invest, reflecting photosynthetic capacity, which may be important for plant growth and establishment (Poorter 1999; Villar et al. 2008). Therefore, it would be necessary to extend field studies on seedlings growing in a heterogeneous environment by including more morphological variables (Pérez-Ramos et al. 2010).

The genus Quercus is widely represented in the Mediterranean basin. Evergreen species (e.g. Quercus ilex L. subsp. ballota and Quercus suber L.) are abundant in the dry Mediterranean mountains of southern Spain; in contrast, semi-deciduous and deciduous species (e.g. Quercus faginea Lam. and Quercus pyrenaica Willd) are scantier and occupy areas with greater water availability owing to their lower drought tolerance (Urbieta et al. 2008b). Moreover, deciduous oaks usually have higher leaf areas and growth rates than evergreens (Ruiz-Robleto and Villar 2005; Quero et al. 2006).

In this work, we expected to find a spatial pattern of environmental factors which may be related to the spatial pattern of both the establishment and growth of Quercus seedlings. Moreover, we assumed that seed size could act as an intrinsic variable with an important role in the studied variables (morphology, biomass and establishment). Specifically, we have covered four primary purposes (a) to explore small-scale spatial heterogeneity of three environmental factors with a high impact on the Mediterranean region (light, soil moisture and herbaceous production); (b) to assess the influence of these factors on the spatial patterns for seedling emergence, growth and survival in four Quercus species differing in leaf longevity; (c) to study changes in the aggregation spatial patterns for plant survival and establishment success during the dry period; and (d) to explore the influence of seed mass and environmental factors on growth and morphology in these species developing under natural field conditions.

\section{Material and methods}

\subsection{Study area and species}

The experiment was conducted in the "Sierra de Cardeña y Montoro" Natural Park (Sierra Morena, Córdoba, Spain, $\left.38^{\circ} 14^{\prime} 16^{\prime \prime} \mathrm{N}, 4^{\circ} 13^{\prime} 18^{\prime \prime} \mathrm{W}\right)$. The climate is semi-humid 
Mediterranean, with continental variations and summer droughts. Annual rainfall ranges from 570 to $970 \mathrm{~mm}$, and the mean annual temperature is $15.3^{\circ} \mathrm{C}$. Soils are regosols and consist mainly of sand with granite as bedrock (Quero et al. 2007). The experimental site, which was fenced to exclude large herbivores, was an open forest of $Q$. ilex L. subsp. ballota (Desf.) with sparse individuals of Pinus pinaster Aiton and Cistus ladanifer L. shrubs. The area has smooth hills with a mean altitude of $480 \mathrm{~m}$. Two evergreen species $(Q$. ilex L. subsp. ballota and $Q$. suber L.) and two deciduous species ( $Q$. faginea Lam. and $Q$. pyrenaica Willd) were selected for the study. The four species coexist in the protected area and exhibit regeneration problems derived from very low seedling and sapling recruitment mainly from the effects of herbivory and summer droughts.

\subsection{Experimental design}

Acorn collection was carried out in autumn 2006. In order to reduce effects of genetic variability, acorns of each species were selected from one mother tree for each species from the vicinity of the experimental site. Acorns were stored in a refrigeration chamber at $2-5^{\circ} \mathrm{C}$ until sowing. Any acorns exhibiting holes or signs of rot were discarded. For each species, a random sub-sample of seeds was used to calculate predictors of seed dry mass. For that, fresh mass and dry mass of each acorn were determined after oven-drying at $70^{\circ} \mathrm{C}$ for at least $48 \mathrm{~h}$ and removing the pericarp from the cotyledons. Linear regression equations of acorn fresh mass against seed dry mass were generated for each species (in all cases $R^{2}>0.90, P<0.05$ ) and were used to estimate the seed dry mass of each acorn used in the experiment, based on its fresh mass.

The study was conducted in two $40 \times 40$-m plots. In each $40 \times 40$-m plot, 121 sampling points were established using a $4 \times 4-m$ sampling grid. To achieve a spatially explicit design, $x$ and $y$ coordinates of each sampling point were determined. The two plots were $50 \mathrm{~m}$ apart. In January 2007 , one acorn of each species was weighed and sown (buried about $5 \mathrm{~cm}$ deep) at each sampling point. The distance between acorns of each species at each node was about $20 \mathrm{~cm}$. This minimized competition between individuals since Quercus seedlings produce a pivot root.

\subsection{Data collection}

Seedlings were monitored for emergence and survival twice a month between January and September 2007. Mean emergence date ranged from $108 \pm 17$ days $(Q$. suber, plot $2)$ to $120 \pm 18$ days $(Q$. ilex and $Q$. pyrenaica, plot 1$)$ after sowing. Emergence was calculated as percentage of seeds emerging from the sown seeds. Survival was calculated as percentage of seedlings surviving from the emerged seeds and the seedling establishment success as a percentage of seedlings surviving from the sown seeds. At the beginning of the growing season (March-April), seedlings were subjected to the following measurements: stem length and both basal and apical diameter of principal and secondary branches.

The data were used to calculate the total stem volume for each plant, using the truncated cone formula. Total leaf area was estimated according to Poorter et al. (2004), using a point grid printed on a transparent sheet.

In a subsample of seedlings (15-25 plants per species) sown in the experimental site but outside the two plots, non-destructive measurements were taken, and after that, they were harvested. Leaf area was calculated, and leaves and stems were dried at $70^{\circ} \mathrm{C}$ and weighed. Linear regressions between stem volume and stem dry weight for each species and sampling date $\left(R^{2}>0.75\right)$ were used to estimate stem mass from the previously calculated volume (Pérez-Ramos et al. 2010). Leaf mass per unit area (LMA) was calculated as the ratio of leaf dry mass to leaf area. Because LMA depends on both the particular species and incident light (Aranda et al. 2004; Poorter et al. 2009), linear regressions between LMA and light availability (global site factor, GSF) were calculated for each species in order to obtain accurate estimates of LMA in relation to GSF $\left(R^{2}>0.40\right)$. LMA and the leaf area estimates were used to calculate leaf dry mass per seedling.

At the end of the growing season (July 2007), dead seedlings were harvested for calculation of stem and leaf dry weight. No significant differences in spring aerial seedling biomass were found between seedling which survived after summer and those which did not survive. Therefore, seedling biomass of dead seedlings could be assumed to be representative of the population. In those seedlings measured on both sampling dates (beginning and end of the growth season) stem relative growth rate $\left(\mathrm{RGR}_{\mathrm{t}}\right)$ and aboveground relative growth rate $\left(\mathrm{RGR}_{\mathrm{a}}\right)$ were calculated as:

$\mathrm{RGR}=\left(\ln M_{2}-\ln M_{1}\right) / t$,

$M_{1}$ and $M_{2}$ were biomass (aboveground or stems) at the beginning and at the end of the growing season, respectively, and $t$ is the time interval between the two measurements. Aerial leaf mass fraction $\left(\mathrm{LMF}_{\mathrm{a}}\right)$ was calculated at the end of the growth season $\left(t_{2}\right)$ as:

$\mathrm{LMF}_{\mathrm{a}}=M_{\mathrm{l}} / M_{t}$,

$M_{1}$ was leaf mass, and $M_{t}$ was total aboveground biomass, both estimated at $t_{2}$.

Environmental variables (light availability, soil moisture and herbaceous production) were measured at each node. 
For simplicity, herbaceous production was called an "environmental variable" because it was studied as an external factor that could influence seedling growth and establishment. Light availability was estimated via the GSF (Rich 1989), using hemispherical photographs taken with a Coolpix camera fitted with an FC E8 fish eye lens, both from Nikon (Tokyo, Japan), in the spring of 2007. Photographs were processed with the software Hemiview Canopy Analysis version 2.1 (Delta-T, Cambridge, UK). Soil moisture was measured as the volumetric content of water (with TDR, Model 100, Spectrum Technologies, Inc., Plainfield, IL, USA) at each sampling point on a monthly basis from February to September 2007. Herbaceous aboveground biomass was harvested in July 2007 within a $25 \times 25-\mathrm{cm}$ square centred at each sampling point and oven-dried in a stove at $70^{\circ} \mathrm{C}$ for at least $48 \mathrm{~h}$ prior to determining dry weight.

\subsection{Statistical analysis}

The spatial pattern for the studied variables was examined by Spatial Analysis by Distance Indices (SADIE) (Perry 1998) as implemented in SadieShell version 1.3 (www. rothamsted.ac.uk/pie/sadie). The spatial pattern for each factor was assessed in terms of the aggregation index $\left(I_{\mathrm{a}}\right)$ and clustering index $(v) . I_{\mathrm{a}}$ provides information on the global spatial pattern in the variable concerned; depending on whether $I_{\mathrm{a}}$ is unity, greater than unity or less than unity, the pattern is usually random, aggregate or regular, respectively (Maestre et al. 2003). Clustering index $(v)$ measures the degree of clustering of the data into patches (areas of high values of the target variable) and gaps (areas of low values); because $v$ is a continuous variable, data can be mapped by kriging (Legendre and Legendre 1998) showing patches and gaps (zones with $v \geq 1.5$ and $v \leq 1.5$, respectively; Perry and Dixon 2002). A separate SADIE analysis was performed per environmental variable and species. Continuous variables were categorized according to Maestre and Quero (2008).

A spatial covariance analysis was performed in order to identify spatial coincidences between aggregated zones for the different variables detected with $v$ (Perry and Dixon 2002). SADIE measurements provided an overall clustering index $X$, ranging from -1 to 1 , which measures whether two variables are spatially associated, dissociated or not related. Indeed, $X$ is the correlation coefficient between the values of $v$ of two variables (Perry et al. 2002). Likewise, they provided a local clustering index $\chi$, which estimates the contribution of each sampling unit to the overall clustering pattern. Like the clustering index $(v)$, these two indices are continuous and provide mapping in order to better envisage zones of spatial association and spatial dissociation between pairs of variables. Maps were produced by linear interpolation with the software SURFER version 8 (Golden Software, Inc.).
Since no spatial aggregation was detected in all the growth and morphology variables (except for four cases from 72, see Section 3), these data were assumed to be space-independent. Thus, growth and morphology variables were compared across species and between the two plots by a two-way analysis of variance (ANOVA) (plot and species as categorical factors). When necessary, a logarithmic transformation of the data was made to fulfil the requirements of normality and variance homoscedasticity. A nonparametric Kruskal-Wallis test was applied in those cases where the transformed data failed to fulfil the ANOVA assumptions.

A multiple regression analysis (forward stepwise method) was applied in order to identify the environmental factors influencing growth and morphology in each species and plot. Model fit was evaluated using the adjusted $R^{2}$. On each model, error terms and $y$ values were normally distributed and had constant variance. Absence of collinearity across dependent variables was checked as the variance inflation factor (FIV) that was in all cases lower than two (Graham 2003). Non-spatial statistical analyses were made with the software STATISTICA 8.0. (Statsoft, Inc.) and R version 2.9.1 (R Development Core Team 2009).

\section{Results}

\subsection{Spatial aggregation in environmental factors}

Most of the environmental variables studied (light availability, soil moisture at different times and herbaceous production) changed according to an aggregated spatial pattern ( 9 out of 12 cases presented spatial aggregation, Table 1). Herbaceous production in plot 1 exhibited the highest aggregation index $\left(I_{\mathrm{a}}\right.$, Table 1). The clustering index maps $[v]$ (Fig. 1) showed patches and gaps for some selected variables. Although the overall pattern was random in some cases (e.g. maximum spring moisture in plot 1), there were zones of significant local aggregation.

\subsection{Spatial pattern in emergence, survival, establishment} success and growth

Emergence ranged from $38 \%$ for $Q$. faginea in plot 1 to $64 \%$ for $Q$. suber in plot 2 (Table 2). Only $Q$. ilex in plot 1 and $Q$. pyrenaica in plot 2 exhibited a spatial aggregation pattern for emergence.

Survival at the end of the summer (September) ranged from $1 \%$ for $Q$. pyrenaica in both plots to $36 \%$ for $Q$. ilex in plot 1 (Table 2). Most species exhibited lower survival in plot 2. Survival at the end of the summer displayed an aggregation pattern for $Q$. ilex and $Q$. suber in plot 1; however, the spatial pattern could not be assessed in plot 2 
Table 1 Means, standard deviations, ranges and aggregation indices $\left(I_{\mathrm{a}}\right)$ for the measured variables in the two studied plots

\begin{tabular}{llll}
\hline & & Plot 1 & Plot 2 \\
\hline Light (GSF) & Mean \pm sd & $0.43 \pm 0.12$ & $0.60 \pm 0.13$ \\
& Min-Max & $0.18-0.68$ & $0.23-0.83$ \\
Mean soil moisture growing season (\%) & $I_{\mathrm{a}}$ & $1.6^{* *}$ & $1.4^{* *}$ \\
& Mean $\pm \mathrm{sd}$ & $10.84 \pm 1.99$ & $11.0 \pm 3.2$ \\
& Min-Max & $6.6-21.9$ & $5.6-31.4$ \\
Maximum soil moisture growing season (\%) & $I_{\mathrm{a}}$ & $1.2 \mathrm{~ns}$ & $1.4^{* *}$ \\
& Mean $\pm \mathrm{sd}$ & $15.7 \pm 3.7$ & $17.2 \pm 5.3$ \\
& Min-Max & $8-41$ & $5-45$ \\
July soil moisture (\%) & $I_{\mathrm{a}}$ & $1.1 \mathrm{~ns}$ & $1.4^{*}$ \\
& Mean $\pm \mathrm{sd}$ & $1 \pm 0.9$ & $0.3 \pm 0.5$ \\
September soil moisture $(\%)$ & Min-Max & $0-3$ & $0-2$ \\
& $I_{\mathrm{a}}$ & $1.9^{* * *}$ & $1.7^{* *}$ \\
& Mean $\pm \mathrm{sd}$ & $6.0 \pm 1$ & $5.5 \pm 1.2$ \\
& Min-Max & $4-10$ & $4-11$ \\
& $I_{\mathrm{a}}$ & $1.3^{*}$ & $1.4^{* *}$ \\
& Mean $\pm \mathrm{sd}$ & $5.02 \pm 4.87$ & $6.6 \pm 3.8$ \\
& Min-Max & $0-39.7$ & $0.10-20.41$ \\
& $I_{\mathrm{a}}$ & $2.4^{* * *}$ & $1.3^{\mathrm{a}}$ \\
\hline
\end{tabular}

The spatial pattern is aggregated when $I_{\mathrm{a}}$ is significant and greater than unity. $I_{\mathrm{a}}$ values less than unity values correspond to a regular pattern and near-unity values to a random pattern. The growing season spanned from February to May

$n s$ not significant

${ }^{\text {a }} P<0.07$

$* P<0.05 ; \quad * * P<0.01 ; * * * P<$ 0.001
Establishment success (a combination of emergence and survival) at the end of the summer was generally higher for the evergreens $Q$. ilex $(20 \%)$ and $Q$. suber $(15 \%)$ than the deciduous species $Q$. faginea $(5 \%)$ and $Q$. pyrenaica $(2 \%)$ due to the low number of living plants remaining. The aggregation pattern for survival persisted over time (July to September); thus, if survival was aggregated at the beginning, it remained aggregated at the end of the summer.

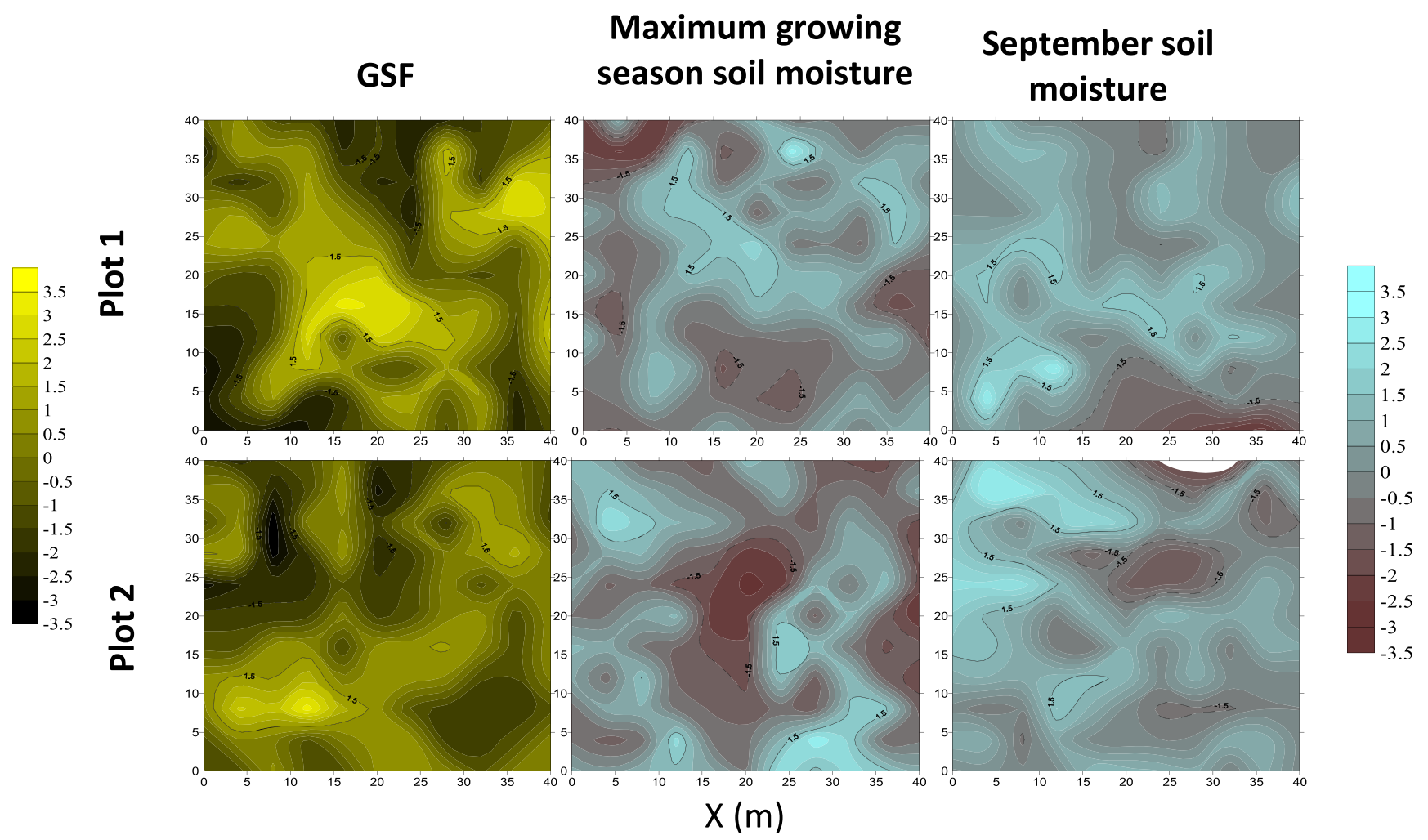

Fig. 1 Maps of clustering indices $(v)$ for selected variables in each sampled plot. The zones bounded by solid lines are patches with high values $(v>1.5)$ in the variable concerned and those bounded by dashed lines gaps of low values in the variable $(v<1.5)$ 
Table 2 Emergence and temporal variation of plant survival and establishment success for the four species in the two studied plots

\begin{tabular}{|c|c|c|c|c|c|c|c|c|}
\hline \multirow{2}{*}{$\begin{array}{l}\text { Plot } 1 \\
\text { Q. ilex }\end{array}$} & \multicolumn{2}{|c|}{ Emergence } & \multirow{2}{*}{$\begin{array}{l}\begin{array}{l}\text { July } \\
\text { survival }\end{array} \\
78.2\end{array}$} & \multirow{2}{*}{$\begin{array}{l}\begin{array}{l}\text { August } \\
\text { survival }\end{array} \\
44.9\end{array}$} & \multirow{2}{*}{$\begin{array}{l}\text { September } \\
\text { survival }\end{array}$} & \multirow{2}{*}{$\begin{array}{l}\begin{array}{l}\text { July } \\
\text { success }\end{array} \\
44.6\end{array}$} & \multirow{2}{*}{$\begin{array}{l}\begin{array}{l}\text { August } \\
\text { success }\end{array} \\
25.6\end{array}$} & \multirow{2}{*}{$\begin{array}{l}\begin{array}{l}\text { September } \\
\text { success }\end{array} \\
20.6\end{array}$} \\
\hline & $\%$ & 57.0 & & & & & & \\
\hline & $1 / 0$ & $69 / 52$ & $54 / 15$ & $31 / 38$ & $25 / 44$ & $54 / 67$ & $31 / 90$ & $25 / 96$ \\
\hline & $I_{\mathrm{a}}$ & $1.36^{* *}$ & $1.22 \mathrm{a}$ & $1.71 * * *$ & $1.54 * *$ & $1.62 * * *$ & $1.91 * * *$ & $1.69 * * *$ \\
\hline \multirow[t]{3}{*}{ Q. suber } & $\%$ & 60.3 & 74.0 & 31.5 & 24.7 & 44.6 & 19.0 & 14.9 \\
\hline & $1 / 0$ & $73 / 48$ & $54 / 19$ & $23 / 50$ & $18 / 55$ & $54 / 67$ & $23 / 98$ & $18 / 103$ \\
\hline & $I_{\mathrm{a}}$ & $0.92 \mathrm{~ns}$ & $1.27 *$ & $1.3 \mathrm{a}$ & $1.28^{*}$ & $1.32 *$ & $1.31^{*}$ & $1.31 *$ \\
\hline \multirow[t]{3}{*}{ Q. faginea } & $\%$ & 38.0 & 60.9 & 24.3 & 15.0 & 23.1 & 7.4 & 4.9 \\
\hline & $1 / 0$ & $46 / 75$ & $28 / 18$ & $9 / 37$ & $6 / 40$ & $28 / 93$ & $9 / 111$ & $6 / 115$ \\
\hline & $I_{\mathrm{a}}$ & $1.11 \mathrm{~ns}$ & $1.14 \mathrm{~ns}$ & $1.63 * *$ & - & $1.02 \mathrm{~ns}$ & $1.35^{*}$ & $1.05 \mathrm{~ns}$ \\
\hline \multirow[t]{3}{*}{ Q. pyrenaica } & $\%$ & 58.7 & 50.7 & 5.6 & 1.4 & 29.8 & 3.3 & 2.5 \\
\hline & $1 / 0$ & $71 / 50$ & $36 / 35$ & $4 / 67$ & $1 / 70$ & $36 / 85$ & $4 / 117$ & $1 / 120$ \\
\hline & $I_{\mathrm{a}}$ & $0.95 \mathrm{~ns}$ & $1.38^{*}$ & - & - & $1.14 \mathrm{~ns}$ & - & - \\
\hline \multirow[t]{2}{*}{ All species } & $\%$ & 52.1 & & & & 35.7 & 14.0 & 10.5 \\
\hline & $I_{\mathrm{a}}$ & $1.03 \mathrm{~ns}$ & & & & $1.56^{* *}$ & $1.94 * * *$ & $1.78 * * *$ \\
\hline \multicolumn{9}{|l|}{ Plot 2} \\
\hline \multirow[t]{3}{*}{ Q. ilex } & $\%$ & 47.1 & 59.6 & 19.3 & 15.8 & 28.1 & 9.1 & 8.3 \\
\hline & $1 / 0$ & $57 / 64$ & $34 / 23$ & $11 / 46$ & $9 / 48$ & $34 / 87$ & $11 / 110$ & $9 / 112$ \\
\hline & $I_{\mathrm{a}}$ & $0.86 \mathrm{~ns}$ & $0.86 \mathrm{~ns}$ & $1.15 \mathrm{~ns}$ & - & $0.88 \mathrm{~ns}$ & - & - \\
\hline \multirow[t]{3}{*}{ Q. suber } & $\%$ & 64.4 & 53.8 & 6.4 & 2.5 & 34.7 & 4.1 & 3.3 \\
\hline & $1 / 0$ & $78 / 43$ & $42 / 36$ & $5 / 73$ & $2 / 76$ & $42 / 79$ & $5 / 116$ & $2 / 119$ \\
\hline & $I_{\mathrm{a}}$ & $1.3^{\mathrm{a}}$ & $1.17 \mathrm{~ns}$ & - & - & $0.92 \mathrm{~ns}$ & - & - \\
\hline \multirow[t]{3}{*}{ Q. faginea } & $\%$ & 41.3 & 37.3 & 2.0 & 2.0 & 15.7 & 0.8 & 0.8 \\
\hline & $1 / 0$ & $50 / 71$ & $19 / 31$ & $1 / 49$ & $7 / 43$ & $19 / 102$ & $1 / 120$ & $7 / 114$ \\
\hline & $I_{\mathrm{a}}$ & $1.02 \mathrm{~ns}$ & $0.93 \mathrm{~ns}$ & - & - & $0.97 \mathrm{~ns}$ & - & - \\
\hline \multirow[t]{3}{*}{$Q \cdot$ pyrenaica } & $\%$ & 62.8 & 23.7 & 1.4 & 1.4 & 14.9 & 0.8 & 0.8 \\
\hline & $1 / 0$ & $76 / 45$ & $18 / 58$ & $1 / 75$ & $1 / 75$ & $18 / 103$ & $1 / 120$ & $1 / 120$ \\
\hline & $I_{\mathrm{a}}$ & $1.31^{*}$ & $1.40^{* *}$ & - & - & $1.57^{* *}$ & - & - \\
\hline \multirow[t]{2}{*}{ All species } & $\%$ & 55.2 & & & & 23.3 & 3.7 & 3.9 \\
\hline & $I_{\mathrm{a}}$ & $0.92 \mathrm{~ns}$ & & & & $1.11 \mathrm{~ns}$ & $1.39 *$ & $1.33^{*}$ \\
\hline
\end{tabular}

$1 / 0$ denotes the number of studied cases. The codes are for emergence: (1) the number of emerged and (0) non-emerged; for survival: (1) alive and (0) dead and for establishment success: (1) alive and (0) dead or non-emerged plants. The number of cases in the entry "All species" has been omitted because points exhibited values from 0 to 4 (see Section 2). An aggregation index $\left(I_{\mathrm{a}}\right)$ less than 1 corresponds to a regular pattern and a near-unity one to a random pattern. The spatial pattern is aggregated when $I_{\mathrm{a}}$ is significant and greater than unity. The dashes in some entries indicate that spatial aggregation could not be assessed owing to the scarcity of cases in some category

$n s$ not significant

${ }^{\mathrm{a}} P<0.07$

$* P<0.05 ; * * P<0.01 ; * * * P<0.001$

in plot 1 (Table 2). A similar pattern, but with a lesser establishment success was found in plot 2 (Table 2). Establishment success in July, where an adequate number of plants for assessment of each species remained, exhibited an aggregation pattern in $Q$. ilex and $Q$. suber in plot 1 (Table 2, Fig. 2). The pattern for $Q$. ilex reflected aggregation in both emergence and survival, whereas that for $Q$. suber was aggregated in survival only. On the other hand, only $Q$. pyrenaica in plot 2 exhibited aggregation in establishment success, reflecting aggregation in both emergence and survival in July (Table 2, Fig. 2). Establishment success for the four species together was aggregated in the three sampling months except in plot 2 in July, although there were small patches of local aggregation (Fig. 2). As in survival, the aggregation patterns for establishment success persisted throughout the dry period. Also, low-success gaps increased during the dry season (July to September, Appendix). Success for all species together at the end of the summer also showed an aggregation pattern (Fig. 3a).

No spatial aggregation in plant growth was detected in growth-related parameters (leaf mass, aerial and total stem mass, $\mathrm{RGR}_{\text {stem }}$ and $\mathrm{RGR}_{\text {aerial }}$ ) in the four species. Only Q. ilex 


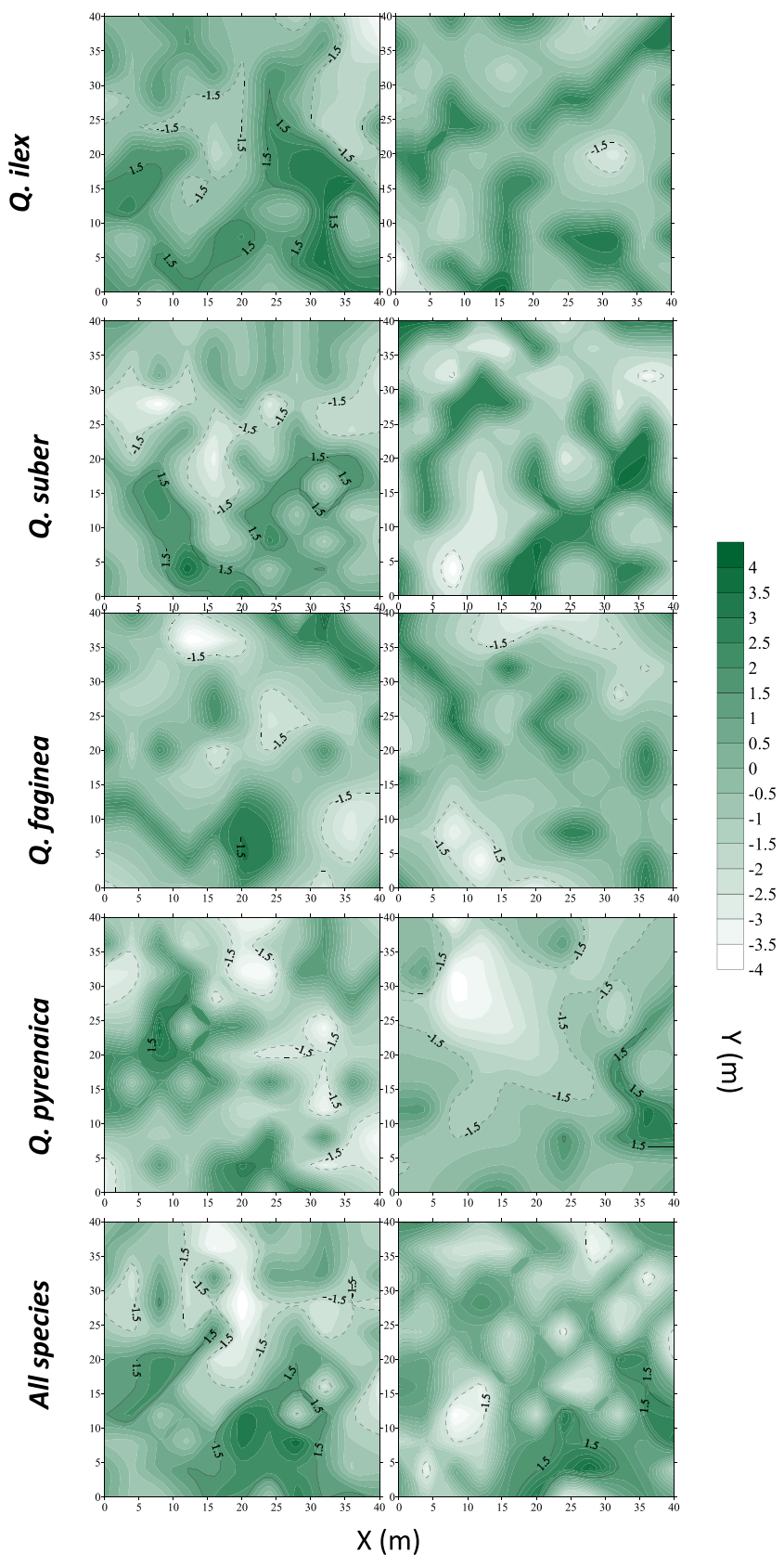

Fig. 2 Maps of clustering indices $(v)$ for establishment success (living seedlings with respect to dead or non-emerged plants) in the four species and both studied plots in July. For details, see Fig. 1

in plot 1 exhibited an aggregated spatial pattern in stem biomass, leaf area and $\mathrm{RGR}_{\text {stem }}$, and in stem height in plot 2 (Appendix).

\subsection{Spatial covariance between variables}

Some variables were found to exhibit a significant positive association (Table 3). Thus, plot 1 displayed covariance between light availability (GSF) and moisture in September. Also, establishment success for $Q$. ilex in July was spatially associated with moisture in the same month. There was no spatial covariance, however, between other environmental factors and emergence or survival of the studied species in this plot. Stem biomass for $Q$. ilex in plot 1 was spatially associated with light availability.

There was a spatial association between maximum moisture in spring and moisture in September in plot 2. Regarding Quercus sowing-related variables, there was a spatial association between emergence of $Q$. pyrenaica and maximum moisture in spring, especially in a zone where low moisture levels led to low oak emergence percentage. Plot 2 also exhibited spatial association between sowing success in all species at the end of the summer and moisture in July. In this case, there was a local gap where low moisture levels corresponded to zones of little or no sowing success (Fig. 3b).

Herbaceous production in plot 2 was spatially associated with light availability and establishment success for $Q$. pyrenaica in July (Table 3 ), i.e. this species was especially successful in zones with an abundant herbaceous cover.

\subsection{Non spatial analysis of growth}

\subsubsection{Interspecific and site differences}

Stem height varied across species and both plots, this being generally higher in plot $2(P=0.01)$ (Appendix). Q. suber seedlings were the tallest. Aboveground biomass and $\mathrm{RGR}_{\mathrm{a}}$ showed significant differences across species. $Q$. faginea had the highest aboveground biomass and $Q$. pyrenaica the lowest. $\mathrm{RGR}_{\mathrm{a}}$ was higher in $Q$. faginea and $Q$. suber. Leaf area, $\mathrm{LMF}_{\mathrm{a}}$ and $\mathrm{RGR}_{\mathrm{t}}$ were similar in different species and plots (Appendix).

\subsubsection{Factors affecting growth and morphology}

Seed mass was one of the best predictors for growth and morphology as it appears in $39 \%$ of the 48 models fitted (six variables per species and plot), this being the factor mainly selected in models of plot 1 (Table 4). Figure 4 shows the positive seed mass-aboveground biomass relationship in plot 1 .

Environmental variables were more explanatory on plot 2, and they appeared as the best predictors either with or without seed mass effect (Table 4). Soil moisture effects were always positive on morphology and growth variables. Seed mass effect was positive in all cases except on $\mathrm{LMF}_{\mathrm{a}}$ of $Q$. pyrenaica in plot 2 . Light effect was positively related with aboveground biomass of $Q$. pyrenaica in plot 1 , and negatively correlated with stem height of $Q$. ilex in plot 2 . Herbaceous production effect was negative in all cases apart from stem height of $Q$. ilex in plot 2 (Table 4 and Fig. 5).

Adjusted $R^{2}$ varied from 0.06 to 0.31 . In general, the model explaining aboveground biomass and RGR fitted better than those related to leaf traits (Table 4). 
A

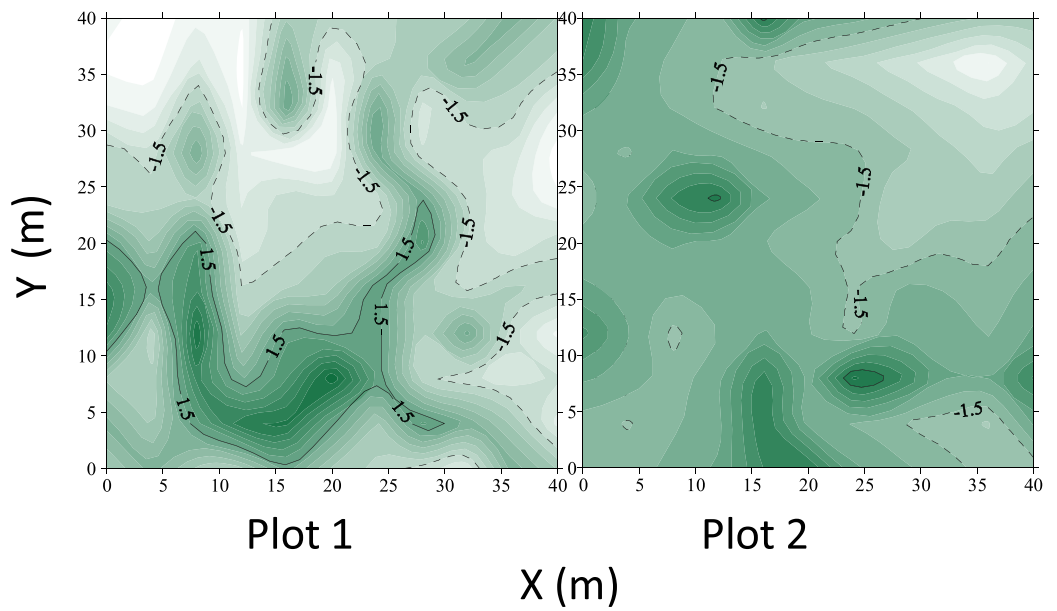

B

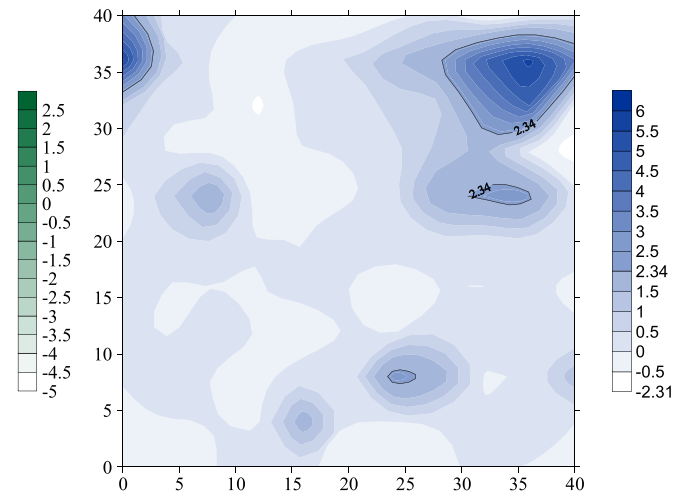

Fig. 3 a Maps of clustering indices $(v)$ for establishment success (living seedlings with respect to dead or non-emerged plants) in the four species and both studied plots in September. For a description of patches and gaps, see Fig. 1. b Map of covariance between moisture in

\section{Discussion}

In this work, we found that the environmental variables studied (light availability, soil moisture, and herbaceous production) had an aggregated spatial pattern along the space, but a low spatial covariance among them, thus showing a high complexity in their spatial relationships. Soil moisture during the dry season was the variable which could explain the spatial aggregation pattern of establishment success. Spatial pattern in survival and establishment success varied across functional groups (evergreens vs deciduous) the aggregated pattern being more frequent in evergreen species. Surprisingly, seedling growth and morphology did not present aggregated patterns and depended more on seed mass than on environmental factors.

\subsection{Environmental factors}

The primary aim of this work was to characterize the spatial distribution and potential association between environmental
July and sowing success on all species in plot 2. The patches represent association zones and the gaps dissociation zones for the variables, and are bounded by lines if significant at the $P<0.05$ level

variables influencing establishment success and growth in woody seedlings. Most environmental variables exhibited an aggregation pattern, showing the small-scale heterogeneity in the environment, that is consistent with previous results of spatial variability in Mediterranean areas (Valladares and Guzmán 2006; Quero et al. 2011). There was, however, virtually no spatial covariance between the environmental variables measured. This suggests, for example, that the study area encompasses high light zones of widely variable soil moisture and vice versa. As a result, the area spans a wide spectrum of microsites, which is consistent with the great complexity of the relationships between these factors (Sack and Grubb 2002; Valladares and Pearcy 2002). Only plot 1 contained a zone where high light levels were associated with high moisture levels in September (after the earliest autumn rains). This may have resulted from the tree canopy intercepting rainwater and the more open zones having increased moisture levels as a consequence of a less marked evaporation in autumn (Tielbörger and Kadmon 2000). Also, there were association patches
Table 3 Summary of spatial covariance between studied variables

\begin{tabular}{ll}
\hline Variables & Plot 1 \\
\hline Light-September soil moisture & $0.28 * *$ \\
Q. ilex success July_-July soil moisture & $0.17 *$ \\
Q. ilex stem mass-light & $0.28 *$
\end{tabular}

Plot 2

Max growing season soil moisture-September soil moisture $\quad 0.16$ *

Light-herbaceous production

Q. pyrenaica emergence-max growing season soil moisture $\quad 0.16$ *

Q. pyrenaica July success-herbaceous production $\quad 0.17$ *

All species September success—July soil moisture $\quad 0.51 * * *$ 
Table 4 Significant predictors in the selected models analysing the response of growth and morphology variables to seed mass and environmental factors $(* P<0.05 ; * * P<0.01 ; * * * P<0.001)$

\begin{tabular}{|c|c|c|c|c|c|c|c|}
\hline \multirow[t]{2}{*}{ Species } & \multirow[t]{2}{*}{ Growth variable } & \multicolumn{3}{|l|}{ Plot 1} & \multicolumn{3}{|l|}{ Plot 2} \\
\hline & & Predictors & Relation & Adjusted $R^{2}$ & Predictors & Relation & Adjusted $R^{2}$ \\
\hline \multirow[t]{6}{*}{$Q i$} & Stem height $t_{1}$ & - & & & light $*$ herb $*$ & -+ & 0.14 \\
\hline & Leaf area $t_{1}$ & - & & & seed mass * & + & 0.07 \\
\hline & Aboveground biomass $t_{2}$ & seed mass $* *$ & + & 0.23 & seed mass * & + & 0.12 \\
\hline & $\mathrm{LMR}_{\mathrm{a}} \mathrm{t}_{2}$ & - & & & - & & \\
\hline & $\mathrm{RGR}_{\mathrm{t}}$ & - & & & seed mass $* *$ & + & 0.14 \\
\hline & $\mathrm{RGR}_{\mathrm{a}}$ & - & & & - & & \\
\hline \multirow[t]{6}{*}{$Q s$} & Stem height $t_{1}$ & - & & & seed mass $*$ soil moisture $*$ & ++ & 0.09 \\
\hline & Leaf area $t_{1}$ & seed mass $*$ & + & 0.08 & - & & \\
\hline & Aboveground biomass $t_{2}$ & seed mass $*$ & + & 0.10 & seed mass $* * *$ soil moisture $*$ & ++ & 0.31 \\
\hline & $\mathrm{LMR}_{\mathrm{a}} \mathrm{t}_{2}$ & - & & & soil moisture $*$ & + & 0.07 \\
\hline & $\mathrm{RGR}_{\mathrm{t}}$ & seed mass $* *$ & + & 0.16 & seed mass $* * *$ & + & 0.24 \\
\hline & $\mathrm{RGR}_{\mathrm{a}}$ & - & & & seed mass $* * *$ & + & 0.16 \\
\hline \multirow[t]{6}{*}{$Q f$} & Stem height $t_{1}$ & - & & & - & & \\
\hline & Leaf area $t_{1}$ & - & & & - & & \\
\hline & Aboveground biomass $t_{2}$ & seed mass $*$ & + & 0.14 & soil moisture $* * *$ herb $* *$ & +- & 0.25 \\
\hline & $\mathrm{LMR}_{\mathrm{a}} \mathrm{t}_{2}$ & - & & & - & & \\
\hline & $\mathrm{RGR}_{\mathrm{t}}$ & seed mass $*$ & + & 0.17 & - & & \\
\hline & $\mathrm{RGR}_{\mathrm{a}}$ & - & & & soil moisture $*$ herb $*$ & +- & 0.14 \\
\hline \multirow[t]{6}{*}{$Q p$} & Stem height $t_{1}$ & - & & & seed mass $* * *$ & + & 0.14 \\
\hline & Leaf area $t_{1}$ & seed mass $*$ & + & 0.06 & seed mass $* *$ & + & 0.11 \\
\hline & Aboveground biomass $t_{2}$ & seed mass $*$ light $*$ & ++ & 0.18 & - & & \\
\hline & $\mathrm{LMR}_{\mathrm{a}} \mathrm{t}_{2}$ & - & & & light $* *$ seed mass $*$ & + & 0.17 \\
\hline & $\mathrm{RGR}_{\mathrm{t}}$ & - & & & seed mass * & + & 0.07 \\
\hline & $\mathrm{RGR}_{\mathrm{a}}$ & - & & & herb $* *$ & - & 0.10 \\
\hline
\end{tabular}

$L M R_{a}$ leaf mass fraction, $R G R_{t}$ stem relative growth rate, $R G R_{a}$ aboveground relative growth rate, $Q i$. ilex, $Q s$. suber, $Q f Q$. faginea, $Q p Q$. pyrenaica

The sign of the effect of the independent variable (positive or negative) and the adjusted $R^{2}$ of the model are also indicated. Herb refers to herbaceous production. Soil moisture reflects mean soil moisture during the growing season

between maximum moisture in spring and moisture in September (after the earliest autumn rains) in plot 2, which is suggestive of a spatial and temporal consistency in soil water availability.

\subsection{Emergence, survival and establishment}

No spatial aggregation patterns for emergence were virtually found. This suggests that emergence is largely independent of environmental factors or that, as noted above, the differential distribution of environmental variables in space conceals their effect on plant performance (Gallardo 2003; Pérez-Ramos et al. 2010). The two exceptional emergence aggregation patterns corresponded to $Q$. ilex in plot 1 and $Q$. pyrenaica in plot 2. The aggregation pattern for $Q$. ilex was not associated with any of the variables studied. On the other hand, that for $Q$. pyrenaica was positively associated with maximum moisture in spring. Therefore, the least moist zone in winter has a strong limiting effect on emergence of $Q$. pyrenaica seedlings, this being consistent with its increased moisture requirements (Costa et al. 1997). Success in this species at the beginning of the dry period was associated with herbaceous biomass. Some studies have shown herbaceous species to use large amounts of water to grow, thereby limiting survival of woody plants at an early growth stage (Davis et al. 1999; Rey Benayas et al. 2005). However, Q. pyrenaica is one of the Quercus species with the highest root investments (Quero et al. 2006), which allows it to evade water competition. In addition, abundance of herbaceous cover may indicate increased light and moisture levels in spring, and, hence, easier establishment of oaks at the emergence stage.

Spatial aggregation in survival and establishment success persisted throughout the studied period. The zones with the 
Fig. 4 Relationship of seedling aboveground biomass at the end of the growing season in plot 1 as a function of seed dry mass. Lines are the regression lines

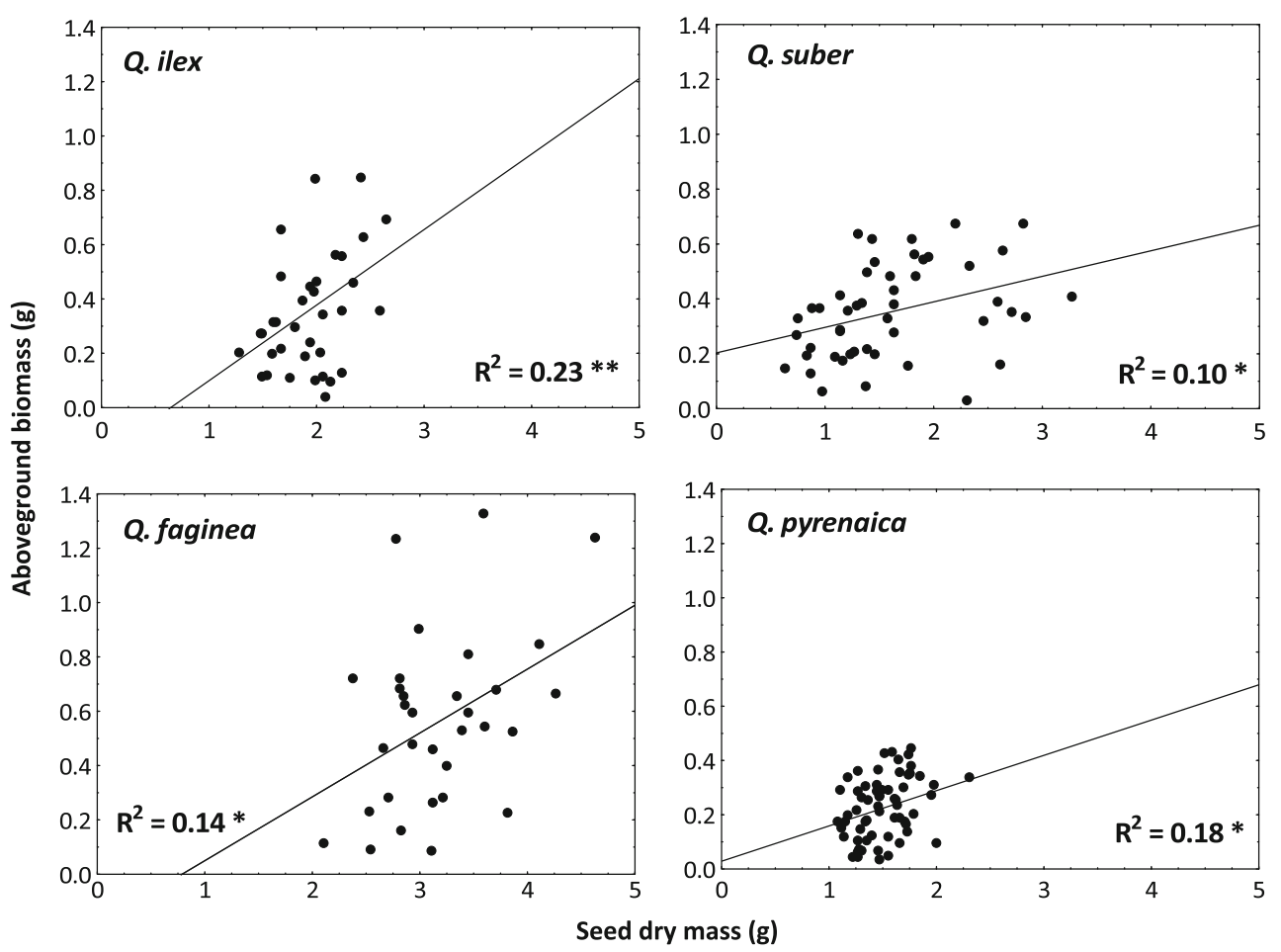

lowest survival percentage expanded as the dry period progressed and the patterns disappeared only when plant mortality was virtually $100 \%$ (deciduous species, $Q$. faginea and $Q$. pyrenaica, in plot 2 at the end of the summer). Some studies (Quero et al. 2011) have found spatial patterns in survival to differ depending on the drought conditions of the year. The differences in soil moisture between the beginning and end of the summer in our study were probably not large enough to alter the aggregation patterns so markedly. Also, Maestre (2006) previously found that survival spatial patterns persisted despite mortality episodes in subsequent years, which suggests that the earliest months of growth are very important for successful establishment. Although precipitation during the study was close to the average for the area $(709 \mathrm{~mm}$ between September 2006 and August 2007), the amount of rainfall collected during the summer (June-August) was only $3 \mathrm{~mm}$. Such a dry summer could have caused both the low survival observed and the disappearance of some spatial patterns. Interestingly, in plot 1 we found aggregation patterns in survival and establishment success for the evergreen species, whereas spatial aggregation was scarce in deciduous ones. Quero et al. (2011) proposed that the spatial pattern may depend on the rainfall of the year, but it is also logical to suggest that, even for the same year, different species may experience drought differently (see below in Section 4.4). Thus, in our study, for evergreen species the extreme event- scant summer rainfallmay not be so extremely perceived whereas for deciduous ones the mortality caused by drought might be so high that the aggregation pattern disappears. Thus, spatial distribution at a small scale depends not only on environmental conditions such as soil moisture or the year's rainfall but also on the species considered.

Establishment success for the four species as a whole exhibited aggregation in both plots, with zones especially favouring the performance of Quercus seedlings. Identifying the zones, which are bounded in order to facilitate regeneration, and examining their persistence may provide useful hints with a view to focusing restoration actions on microenvironments with high survival percentage (Maestre et al. 2006). What are the specific factors governing establishment success? In plot 1, the spatial distribution of light, soil moisture and herbaceous production was not directly associated with success. Plot 2 exhibited some zones where a decrease in moisture during July was associated with a low establishment success. However, other factors such as topography, soil stoniness or nutrient distribution (Maestre et al. 2006) could determine the presence of zones of a low or high establishment success. Water is known to be a major limiting factor in Mediterranean ecosystems, especially during the summer droughts (Herrera et al. 1994). Site factors such as microtopography, vegetation patches or soil type determine spatially and temporally heterogeneity in soil moisture (Quero et al. 2011) influencing species performance. As a result, seedlings in especially dry microsites may have inadequate water resources to survive. Overall, survival and establishment success were lesser in plot 2 than in plot 1, possibly as a result of increasing water stress during the summer in the former as indicated by lower soil moisture in July in plot 2 than plot 1. 
Fig. 5 Relationship of different morphology and growth variables with a light availability, b soil moisture and $\mathbf{c}$ herbaceous production $\left(\mathrm{g} / 0.25 \mathrm{~m}^{-2}\right)$ in different plots. Lines are the regression lines
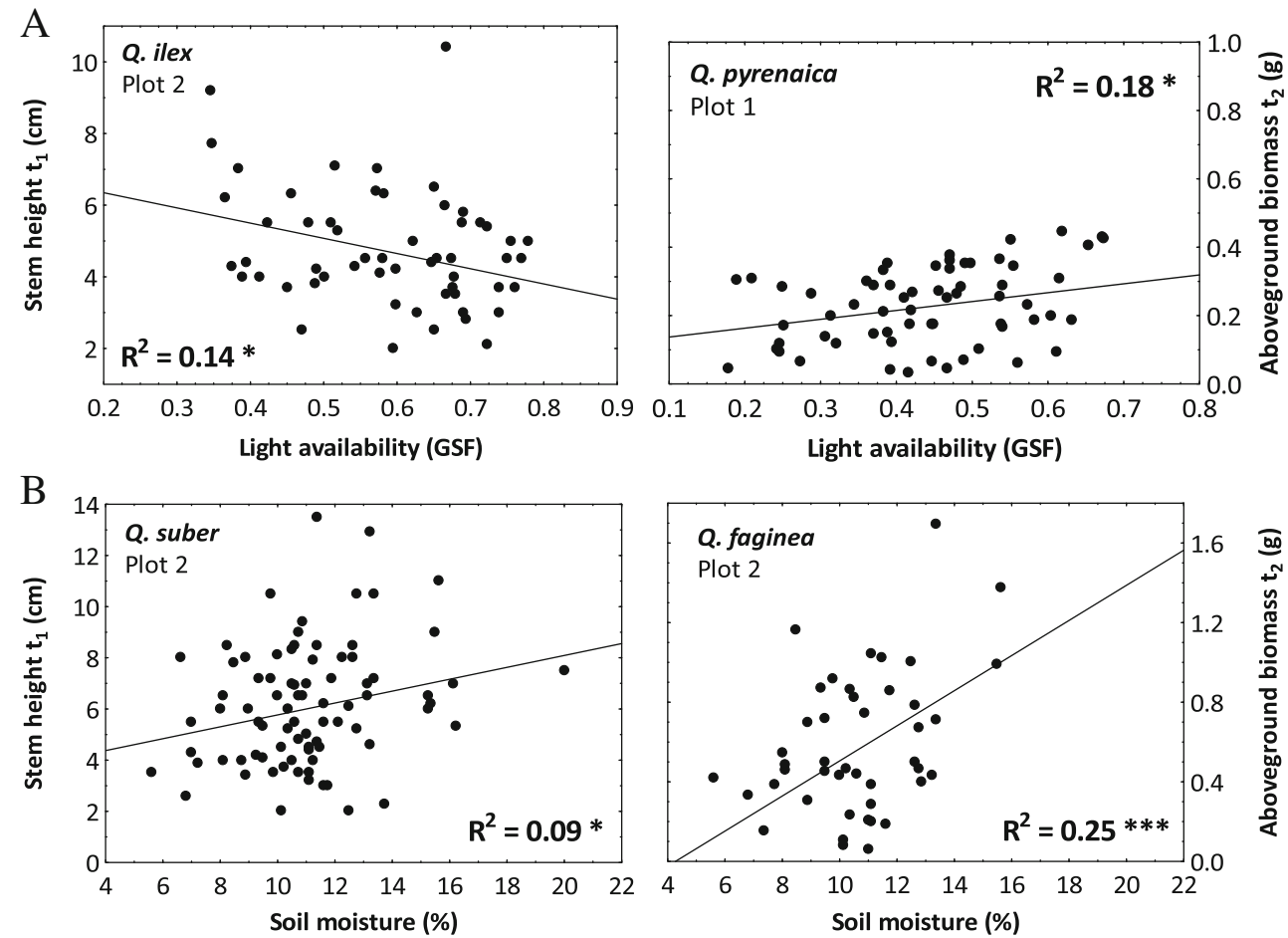

$\mathrm{C}$

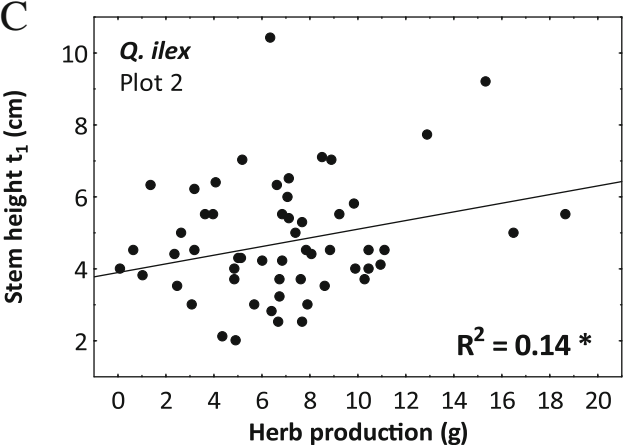

\subsection{Growth and morphology}

Unexpectedly, growth-related variables exhibited virtually no aggregation patterns. Laliberte et al. (2008) found the spatial patterns for stem diameter and height to account for a very low fraction of the overall variance. Pérez-Ramos et al. (2010) and Villar-Salvador et al. (2010) found growth of Quercus seedlings during the first year to depend more markedly on the seed reserves than on the environmental conditions. In our study, seed mass was the main factor explaining growth and morphology, and it was especially important on plot 1 . Seedmass represents the amount of reserves available for growth development in the first stages of seedling development. A larger seed-mass is related to a larger seedling biomass (Quero et al. 2008; González-Rodríguez et al. 2010), which confers some advantages on seedling establishment (Hendrix et al. 1991; Chacón and Bustamante 2001).

In general, variance explained in all models was not very high. Pérez-Ramos et al. (2010) found similar values for first year growth in Quercus species, and the models' fit increased in the second year, in which environmental variables were more explicative. As noted above, it seems that, during the first year, seedlings are more dependent on intrinsic characteristics like seed-mass or other factors such as seed chemical composition, not contemplated in this study but which could be more crucial (Villar-Salvador et al. 2010).

Although environmental variables explained less variance than seed mass, they were selected as predictors in many models in plot 2 whereas they were only included in one model of plot 1 . This confirms the high variability in Mediterranean ecosystems, where, as we have seen, resource availability may change in a few metres, determining two areas very close to each other but in which seedling performance was different.

Light availability is an important resource which determines species distribution in Mediterranean environments (Beckage and Clark 2003; Zavala and Zea 2004). However, it does not appear as a key factor explaining Quercus growth variability. This may be caused by the fact that the growth of 
large-seeded species is less responsive to environmental conditions (Beckage and Clark 2003). Moreover, natural shading in the experimental site was mainly produced by $Q$. ilex, $P$. pinaster and $C$. ladanifer. The two latter species alter physico-chemical properties of the top-soil by emitting allelochemical compounds or modifying the amount of nutrients (Gallardo 2003; Gómez-Aparicio et al. 2005a; Puerta-Piñero et al. 2006). These plant-plant interactions take place in different signs depending on the species, and could hide the specific responses to light availability per se. In fact, Pérez-Ramos et al. (2010) found that light and nutrient availability is negatively related, therefore the effect of each factor may be masked.

According to a similar experiment carried out in Sierra Nevada (Spain) (Gómez-Aparicio et al. 2008), light increased aboveground biomass and leaf mass fraction of Q. pyrenaica. As the canopy intercepts rainfall during the growing season (Aussenac 2000), shaded sites could be occasionally drier, so oak seedlings growing in open and wet areas could be favoured, even though this species is shade tolerant in its early life stages (Quero et al. 2006). On the other hand, stem height of $Q$. ilex increased in the shade. This effect has been previously observed in plants growing in shaded areas (with a reduced R:FR, red:far-red light ratio) (Ziegenhagen and Kausch 1995; Ammer 2003). In this experiment, no deep shaded microsites were represented as they are scant in the study area, so other strong negative relations between light and growth rarely appear. Moreover, the studied species are in general, intermediate or good shade tolerant (Cardillo and Bernal 2006; Quero et al. 2006; Pérez-Ramos et al. 2010).

As observed in survival and establishment, soil moisture during the growing season affected Quercus growth and biomass positively. Holm oak was not influenced by soil moisture, maybe due to its greater drought tolerance (Mediavilla and Escudero 2004; David et al. 2007).

Competition between the herbaceous layer and woody seedlings is mainly for water (Davis et al. 1999; Rey Benayas et al. 2007). In the present study, the herbaceous layer was related to a decrease in $\mathrm{RGR}_{\mathrm{a}}$ and aerial biomass and to an increase of stem height in $Q$. ilex at the beginning of the growing season. Holmgren et al. (2000) found a similar herbaceous effect in Chilean woody seedlings. Competition could be, in this case, for light as well as for water, diminishing aboveground growth in biomass but enhancing height growth in the same way as shade conditions did.

\subsection{Differences across species}

Species differed in survival and establishment success. $Q$. ilex was the most successful species in both plots. This species develops an effective water stress avoiding strategy
(Valladares et al. 2008) and possesses the highest drought resistance (Costa et al. 1997). By contrast, the deciduous species $(Q$. faginea and $Q$. pyrenaica) exhibited a lesser survival, possibly as a result of their lower drought tolerance (Quero et al. 2006; Villar et al. 2008). Q. pyrenaica exhibited virtually no survival or establishment success. This species is scantily represented in Sierra de Cardeña y Montoro, where it only occurs in especially moist areas (Castillo and Castillo 2004).

Species growth differed only slightly in their response to environmental gradients. Other studies have shown how interspecific differences in response to drought and shade disappeared in the first stages of life, when seedlings from different Quercus species showed a common strategy (Mediavilla and Escudero 2004; Quero et al. 2006). A striking outcome of this study is that $Q$. faginea had the highest aboveground biomass at the end of the growing season but this could be an experimental design effect. $Q$. faginea seed mass average was the highest and this trait was positively correlated with seedling mass (see above). On the other hand, the lower aboveground inversion of $Q$. pyrenaica seedlings could be due to the higher root allocation of this species (Quero et al. 2006, 2007).

\section{Conclusions}

Heterogeneity at the microsite level was found to govern the small-scale availability of some resources including light and water, determining that, in the two studied plots, seedling performance was different, although the plots were very close each other. The seedling emergence process appears to be scarcely influenced by the environmental conditions. The same happens for plant growth during the first year, which is more markedly dependent on seed reserves than on the particular environmental conditions. On the other hand, survival and establishment success depend, at least partly, on water availability. A scarcity of this resource can lead to heavily limited survival in some zones. The spatial aggregation patterns for seedling survival and establishment success persist during the dry season and only vanish when plant mortality is very high (e.g. under extremely dry conditions or in species with a high sensitivity to water limitation).

Acknowledgements This study was funded by DINAMED (CGL2005-05830-C03-02/BOS) and INTERBOS (CGL2008-04503C03-02) projects (Spain's Ministry of Science and Innovation), and co-funded by FEDER (European Union). VGR wishes to acknowledge award of a grant and an FPI-MEC pre-doctoral contract (BES2006-13059), and JLQ a MCINN post-doctoral contract (2007-0572). The authors are grateful to J.M. Quero and Pedro Lara for access to "Sierra de Cardeña y Montoro" Natural Park facilities; F. Puig and B. Arévalo for allowing us to collect acorns from their farms. Our group is a member of the Globimed network (www.globimed.net). 


\section{Appendix}

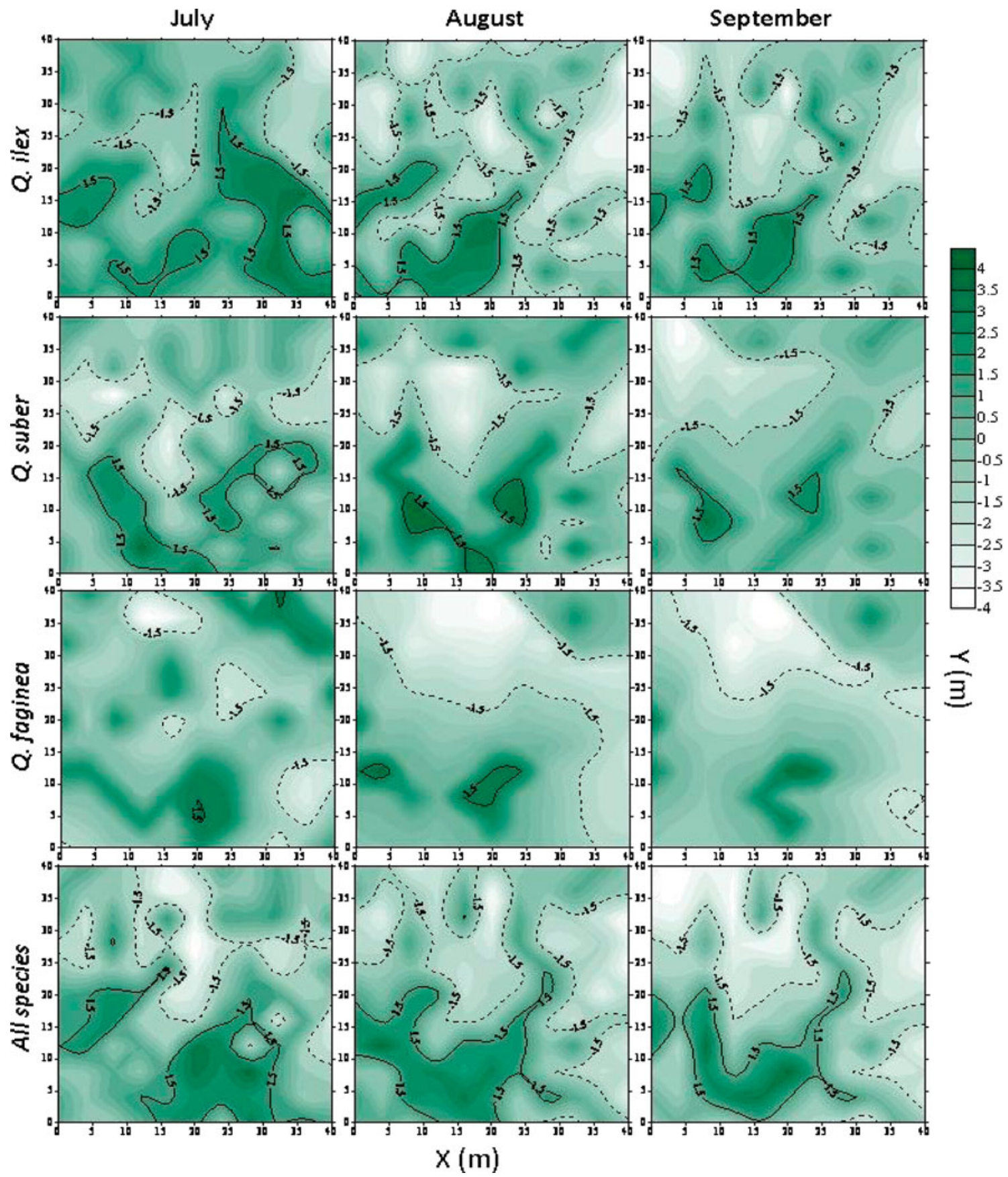

Fig. 6 Maps of clustering indices (v) during the dry season for establishment success (living seedlings versus dead or non-emerged plants) in plot 1 for each species and for all as a whole. No data for plot 2 and for $Q$. pyrenaica in plot 1 are shown since the number of

inadequate to examine their aggregation patterns. The zones bounded by a solid line correspond to patches with high values of the variable $(v>1.5)$ and those bounded by a dashed line gaps with low values of the variable $(v<1.5)$ 
Table 5 Means, standard deviations, ranges and aggregation indices $\left(I_{\mathrm{a}}\right)$ for the different variables related to growth and morphology for the four species in the two plots

\begin{tabular}{|c|c|c|c|c|c|c|c|c|c|}
\hline & & \multicolumn{2}{|l|}{ Q. ilex } & \multicolumn{2}{|l|}{ Q. suber } & \multicolumn{2}{|l|}{ Q. faginea } & \multicolumn{2}{|l|}{ Q. pyrenaica } \\
\hline & & Plot 1 & Plot 2 & Plot 1 & Plot 2 & Plot 1 & Plot 2 & Plot 1 & Plot 2 \\
\hline \multirow[t]{4}{*}{ Stem height $\mathrm{t}_{1}(\mathrm{~cm})$} & Mean \pm ds & $4.28 \pm 1.51 \mathrm{~A}$ & $4.78 \pm 1.64 \mathrm{a}, \mathrm{b}$ & $5.74 \pm 2.21 \mathrm{~B}$ & $6.15 \pm 2.38 \mathrm{c}$ & $5.05 \pm 2.20 \mathrm{~A}, \mathrm{~B}$ & $5.60 \pm 2.28 \mathrm{a}, \mathrm{c}$ & $4.00 \pm 1.56 \mathrm{~A}$ & $3.95 \pm 1.17 \mathrm{~b}$ \\
\hline & Min-Max & $1.5-7.5$ & $2-13.5$ & $1.7-12.3$ & $2-10.4$ & $1.28-12.4$ & $2.5-12$ & $1.5-7.5$ & $1.7-7$ \\
\hline & $I_{\mathrm{a}}$ & $1.13 \mathrm{~ns}$ & $1.35 *$ & $1.09 \mathrm{~ns}$ & $1.18 \mathrm{~ns}$ & $1.03 \mathrm{~ns}$ & $1.01 \mathrm{~ns}$ & $1.08 \mathrm{~ns}$ & $1.10 \mathrm{~ns}$ \\
\hline & $N$ & 61 & 56 & 72 & 82 & 42 & 48 & 68 & 71 \\
\hline \multirow[t]{4}{*}{ Leaf area $t_{1}\left(\mathrm{~cm}^{2}\right)$} & Mean \pm ds & $13.9 \pm 8.33$ & $17.1 \pm 8.6$ & $18.1 \pm 12.3$ & $17.9 \pm 12.6$ & $26.8 \pm 23.2$ & $26.5 \pm 18.9$ & $21.5 \pm 13.3$ & $20.3 \pm 10.6$ \\
\hline & Min-Max & $1.8-35.0$ & $1.5-45.0$ & $1.8-50.9$ & $0.4-68.5$ & $1.3-121$ & $3.75-74.5$ & $3.5-50.0$ & $2.7-52.9$ \\
\hline & $I_{\mathrm{a}}$ & $1.63 * *$ & $0.76 \mathrm{~ns}$ & $0.97 \mathrm{~ns}$ & $1.29 \mathrm{~ns}$ & $1.02 \mathrm{~ns}$ & $1.02 \mathrm{~ns}$ & $0.91 \mathrm{~ns}$ & $0.96 \mathrm{~ns}$ \\
\hline & $N$ & 60 & 57 & 71 & 82 & 40 & 48 & 66 & 71 \\
\hline \multirow[t]{4}{*}{ LMFa $t_{2}$} & Mean $\pm \mathrm{ds}$ & $0.73 \pm 0.18$ & $0.77 \pm 0.12$ & $0.73 \pm 0.07$ & $0.74 \pm 0.06$ & $0.74 \pm 0.10$ & $0.72 \pm 0.12$ & $0.65 \pm 0.17$ & $0.68 \pm 0.18$ \\
\hline & Min-Max & $0.08-0.90$ & $0.21-0.89$ & $0.58-0.87$ & $0.47-0.87$ & $0.33-0.86$ & $0.39-0.86$ & $0.20-0.84$ & $0.08-0.86$ \\
\hline & $I_{\mathrm{a}}$ & $1.28 \mathrm{~ns}$ & $1.11 \mathrm{~ns}$ & $1.05 \mathrm{~ns}$ & $0.85 \mathrm{~ns}$ & $0.88 \mathrm{~ns}$ & $1.21 \mathrm{~ns}$ & $0.89 \mathrm{~ns}$ & $1.71 \mathrm{~ns}$ \\
\hline & $N$ & 33 & 38 & 46 & 68 & 30 & 42 & 63 & 64 \\
\hline \multirow[t]{4}{*}{ Stem mass $t_{2}(g)$} & Mean $\pm \mathrm{ds}$ & $0.08 \pm 0.05$ & $0.08 \pm 0.07$ & $0.09 \pm 0.05$ & $0.10 \pm 0.05$ & $0.14 \pm 0.08$ & $0.14 \pm 0.08$ & $0.07 \pm 0.04$ & $0.08 \pm 0.11$ \\
\hline & Min-Max & $0.02-0.25$ & $0.01-0.40$ & $0.01-0.22$ & $0.01-0.26$ & $0.02-0.36$ & $0.03-0.35$ & $0.02-0.23$ & $0.01-0.71$ \\
\hline & $I_{\mathrm{a}}$ & $1.46 *$ & $1.20 \mathrm{~ns}$ & $1.18 \mathrm{~ns}$ & $0.95 \mathrm{~ns}$ & $0.95 \mathrm{~ns}$ & $0.82 \mathrm{~ns}$ & $0.98 \mathrm{~ns}$ & $0.87 \mathrm{~ns}$ \\
\hline & $N$ & 33 & 38 & 46 & 68 & 30 & 42 & 63 & 64 \\
\hline \multirow[t]{4}{*}{ Leaf mass $t_{2}(\mathrm{~g})$} & Mean $\pm \mathrm{ds}$ & $0.27 \pm 0.18$ & $0.27 \pm 0.15$ & $0.26 \pm 0.13$ & $0.28 \pm 0.17$ & $0.43 \pm 0.25$ & $0.44 \pm 0.30$ & $0.16 \pm 0.10$ & $0.16 \pm 0.11$ \\
\hline & Min-Max & $0.02-0.70$ & $0.03-0.61$ & $0.02-0.54$ & $0.01-0.75$ & $0.03-0.99$ & $0.03-1.34$ & $0.01-0.36$ & $0.02-0.82$ \\
\hline & $I_{\mathrm{a}}$ & $0.78 \mathrm{~ns}$ & $1.04 \mathrm{~ns}$ & $1.05 \mathrm{~ns}$ & $0.92 \mathrm{~ns}$ & $0.96 \mathrm{~ns}$ & $1.03 \mathrm{~ns}$ & $0.85 \mathrm{~ns}$ & $0.90 \mathrm{~ns}$ \\
\hline & $N$ & 33 & 38 & 46 & 68 & 30 & 42 & 63 & 64 \\
\hline \multirow{4}{*}{$\begin{array}{l}\text { Aboveground } \\
{\text { mass } t_{2}(g)}^{(g)}\end{array}$} & Mean $\pm \mathrm{ds}$ & $0.34 \pm 0.21 \mathrm{~A}, \mathrm{~B}$ & $0.35 \pm 0.18 \mathrm{a}, \mathrm{b}$ & $0.35 \pm 0.17 \mathrm{~A}$ & $0.38 \pm 0.22 \mathrm{a}$ & $0.56 \pm 0.32 \mathrm{~A}$ & $0.59 \pm 0.36 \mathrm{c}$ & $0.23 \pm 0.11 \mathrm{~B}$ & $0.24 \pm 0.17 \mathrm{~b}$ \\
\hline & Min-Max & $0.04-0.85$ & $0.03-0.73$ & $0.03-0.67$ & $0.01-0.92$ & $0.08-1.33$ & $0.06-1.69$ & $0.03-0.44$ & $0.05-1.14$ \\
\hline & $I_{\mathrm{a}}$ & $0.89 \mathrm{~ns}$ & $0.96 \mathrm{~ns}$ & $1.09 \mathrm{~ns}$ & $0.91 \mathrm{~ns}$ & $0.98 \mathrm{~ns}$ & $1.01 \mathrm{~ns}$ & $0.88 \mathrm{~ns}$ & $0.72 \mathrm{~ns}$ \\
\hline & $N$ & 33 & 38 & 46 & 68 & 30 & 42 & 63 & 64 \\
\hline \multirow{4}{*}{$\begin{array}{l}\mathrm{RGR}_{\mathrm{s}} \\
\quad\left(\mathrm{mg} \mathrm{g}^{-1} \text { day }^{-1}\right)\end{array}$} & Mean $\pm \mathrm{ds}$ & $12.7 \pm 9.5$ & $14.9 \pm 13.4$ & $13.3 \pm 6.3$ & $11.5 \pm 5.4$ & $15.1 \pm 6.5$ & $15.5 \pm 15.5$ & $15.2 \pm 8.9$ & $13.6 \pm 12.2$ \\
\hline & Min-Max & $1.1-40.5$ & $1.3-74.4$ & $3.1-36.8$ & $1.1-25.3$ & $1.5-26.6$ & $1.52-85.92$ & $0.8-51.6$ & $1.1-64.3$ \\
\hline & $I_{\mathrm{a}}$ & $1.37 *$ & $0.80 \mathrm{~ns}$ & $1 \mathrm{~ns}$ & $0.84 \mathrm{~ns}$ & $0.87 \mathrm{~ns}$ & $0.81 \mathrm{~ns}$ & $1.30 \mathrm{~ns}$ & $0.91 \mathrm{~ns}$ \\
\hline & $N$ & 26 & 38 & 42 & 61 & 30 & 37 & 58 & 55 \\
\hline \multirow{4}{*}{$\begin{array}{l}\mathrm{RGR}_{\mathrm{a}} \\
\quad\left(\mathrm{mg} \mathrm{g}^{-1} \mathrm{day}^{-1}\right)\end{array}$} & Mean \pm ds & $8.3 \pm 7.1 \mathrm{~A}$ & $11.4 \pm 11.7$ & $14.5 \pm 8.6 \mathrm{~B}$ & $13.1 \pm 7.8$ & $13.8 \pm 8.8 \mathrm{~B}$ & $17.6 \pm 8.0$ & $11.1 \pm 8.7 \mathrm{~A}$ & $16.2 \pm 7.6$ \\
\hline & Min-Max & $1.9-25.1$ & $3.8-57.1$ & $2.1-37.8$ & $3.4-46.9$ & $1.6-32.2$ & $9.6-39.5$ & $0.1-39.2$ & $7.5-33.0$ \\
\hline & $I_{\mathrm{a}}$ & $0.98 \mathrm{~ns}$ & $0.84 \mathrm{~ns}$ & $0.89 \mathrm{~ns}$ & $0.85 \mathrm{~ns}$ & $1.21 \mathrm{~ns}$ & $0.94 \mathrm{~ns}$ & $0.95 \mathrm{~ns}$ & $1.01 \mathrm{~ns}$ \\
\hline & $N$ & 18 & 27 & 35 & 54 & 21 & 30 & 39 & 37 \\
\hline
\end{tabular}

$n s$ not significant, $L M F a$ leaf mass fraction aerial is the ratio of leaf mass to aboveground biomass, $R G R_{s}$ relative growth rate of stems, $R G R_{a}$ relative growth rate of aboveground biomass, $t_{1}$ and $t_{2}$ refer to spring and summer, respectively

An aggregation index $\left(I_{\mathrm{a}}\right)$ less than 1 corresponds to a regular pattern and a near-unity one to a random pattern. The spatial pattern is aggregated when $I_{\mathrm{a}}$ is significant and greater than unity. Different letters indicate significant differences $(P<0.05)$ across species at plot 1 (capital letters) and at plot 2 (lower case letters). No difference were found between plots, except from stem height that was higher in plot $2(P=0.01)$. No letters indicate no significant differences

$* P<0.05 ; * * P<0.01 ; * * * P<0.001$

\section{References}

Ammer C (2003) Growth and biomass partitioning of Fagus sylvatica L. and Quercus robur L. seedlings in response to shading and small changes in the R/FR-ratio of radiation. Ann For Sci 60:163-171

Aranda I, Pardo F, Gil L, Pardos JA (2004) Anatomical basis on the change in leaf mass per area and nitrogen investment with relative irradiance within the canopy of eight temperate tree species. Acta Oecol 25:187-195
Aussenac G (2000) Interactions between forest stands and microclimate: ecophysiological aspects and consequences for silviculture. Ann For Sci 57:287-301

Beckage B, Clark JS (2003) Seedling survival and growth of three forest tree species: the role of spatial heterogeneity. Ecology 84:1849-1861

Cardillo E, Bernal CJ (2006) Morphological response and growth of cork oak (Quercus suber L.) seedlings at different shade levels. For Ecol Manag 222:296-301

Castillo PA, Castillo A (2004) Caracterización de las poblaciones de roble melojo (Quercus pyrenaica Willd.) en el Parque Natural de 
la Sierra de Cardeña y Montoro. Determinación de su área potencial a través de S.I.G. Foresta 25:46-51

Castro J, Zamora R, Hódar JA, Gómez JM (2004) Seedling establishment of a boreal tree species (Pinus sylvestris) at its southernmost distribution limit: consequences of being in a marginal Mediterranean habitat. J Ecol 92:266-277

Chacón P, Bustamante RO (2001) The effects of seed size and pericarp on seedling recruitment and biomass in Cryptocarya alba (Lauraceae) under two contrasting moisture regimes. Plant Ecol 152:137-144

Costa M, Morla C, Sainz H (1997) Los bosques ibéricos. Una interpretación geobotánica. Ed. Planeta, Barcelona, Spain, p 572

David TS, Henriques MO, Kurz-Besson C, Nunes J, Valente F, Vaz M, Pereira JS, Siegwolf R, Chaves MM, Gazarini LC, David JS (2007) Water-use strategies in two co-occurring Mediterranean evergreen oaks: surviving the summer drought. Tree Physiol 27:793-803

Davis MA, Wrage KJ, Reich PB, Tjoelker MG, Schaeffer T, Muermann C (1999) Survival, growth, and photosynthesis of tree seedlings competing with herbaceous vegetation along a water-light-nitrogen gradient. Plant Ecol 145:341-350

Gallardo A (2003) Effect of tree canopy on the spatial distribution of soil nutrients in a Mediterranean Dehesa. Pedobiologia 47:117125

García D, Houle G (2005) Fine-scale spatial patterns of recruitment in red oak (Quercus rubra): what matters most, abiotic or biotic factors? Ecoscience 12(2):223-235

Gómez JM, Valladares F, Puerta-Piñero C (2004) Differences between structural and functional environmental heterogeneity caused by seed dispersal. Funct Ecol 18:787-792

Gómez-Aparicio L, Gómez JM, Zamora R (2005a) Microhabitats shift rank in suitability for seedling establishment depending on habitat type and climate. J Ecol 93:1194-1202

Gómez-Aparicio L, Valladares F, Zamora R, Quero JL (2005b) Response of tree seedlings to the abiotic heterogeneity generated by nurse shrubs: an experimental approach at different scales. Ecography 28:757-768

Gómez-Aparicio L, Pérez-Ramos IM, Mendoza I, Matías L, Quero JL, Castro J, Zamora R, Marañón T (2008) Oak seedling survival and growth along resource gradients in Mediterranean forests: implications for regeneration in current and future environmental scenarios. Oikos 117:1683-1699

González-Rodríguez V, Villar R, Navarro-Cerrillo RM (2010) Maternal influences on seed mass effect and initial seedling growth in four Quercus species. Acta Oecol 37:1-9

González-Rodríguez V, Navarro-Cerrillo RM, Villar R (2011) Artificial regeneration with Quercus ilex L. and $Q$. suber L. by direct seeding and planting in southern Spain. Ann For Sci. doi:10.1007/s13595-011-0057-3

Graham M (2003) Confronting multicollinearity in ecological multiple regression. Ecology 84(11):2809-2815

Hendrix SD, Nielsen E, Nielsen T, Schutt M (1991) Are seedlings from small seeds always inferior to seedlings from large seeds? Effects of seed biomass on seedling growth in Pastinaca sativa L. New Phytol 119:299-305

Herrera CM, Jordano P, López-Soria L, Arnat JA (1994) Recruitment of a mast-fruiting bird dispersed tree: bridging frugivore activity and seedling establishment. Ecol Monogr 64:315-344

Holmgren M, Segura AM, Fuentes ER (2000) Limiting mechanisms in the regeneration of the Chilean matorral. Plant Ecol 147:49-57

Jordano P, Pulido F, Arroyo J, García-Castaño JL, García-Fayos P (2008) Procesos de limitación demográfica. In: Ecología del bosque mediterráneo en un mundo cambiante, Ed. Ministerio de Medio Ambiente, Madrid. pp 229-248

Jurena PN, Archer S (2003) Woody plant establishment and spatial heterogeneity in Grasslands. Ecology 84(4):907-919
Laliberté E, Cogliastro A, Bouchard A (2008) Spatiotemporal patterns in seedling emergence and early growth of two oak species direct-seeded on abandoned pastureland. Ann For Sci 65:407

Legendre P (1993) Spatial autocorrelation: trouble or new paradigm. Ecology 74(b):1659-1673

Legendre P, Legendre L (1998) Numerical ecology, 2nd edn. Elsevier Science, Amsterdam, p 853

Leishman MR, Westoby M (1994) The role of large size in shaded conditions: experimental evidence. Funct Ecol 8:205-214

Maestre FT (2006) Linking the spatial patterns of organisms and abiotic factors to ecosystem function and management: Insights from semi-arid environments. Web Ecol 6:75-87

Maestre FT, Quero JL (2008) Análisis espacial mediante índices dedistancia SADIE. In: Maestre FT, Escudero A, Bonet A (eds) Introducción al Análisis Espacial de Datos en Ecología y Ciencias Ambientales: Métodos y Aplicaciones. AEET-CAM, Madrid, pp 129-182

Maestre FT, Cortina J, Bautista S, Bellot J, Vallejo R (2003) Smallscale environmental heterogeneity and spatiotemporal dynamics of seedling establishment in a semiarid degraded ecosystem. Ecosystems 6:630-643

Maestre FT, Bradford M, Reynolds JF (2006) Soil heterogeneity and community composition jointly influence grassland biomass. J Veg Sci 17:261-270

Mediavilla S, Escudero A (2004) Stomatal responses to drought of mature trees and seedlings of two co-occurring Mediterranean oaks. For Ecol Manag 187:281-294

Milton SJ (1995) Spatial and temporal patterns in the emergence and survival of seedlings in arid Karoo shrubland. J Appl Ecol $32: 145-156$

Paynter Q, Fowler SV, Memmott J, Sheppard AW (1998) Factors affecting the establishment of Cytisus scoparius in southern France: implications for managing both native and exotic populations. J Appl Ecol 35:582-595

Pérez-Ramos IM, Gómez-Aparicio L, Villar R, García LV, Marañón T (2010) Seedling growth and morphology of three oak species along field resource gradients and seed-mass variation: a seedling-age-dependent response. J Veg Sci 21:419-437

Perry JN (1998) Measures of spatial pattern for counts. Ecology 79:1008-1017

Perry JN, Dixon P (2002) A new method to measure spatial association for ecological count data. Ecoscience 9:133-141

Perry JN, Liebhold AM, Rosenberg MS, Dungan J, Miriti M, Jakomulska A, Citron-Pousty S (2002) Illustrations and guidelines for selecting statistical methods for quantifying spatial pattern in ecological data. Ecography 25:578-600

Poorter L (1999) Growth responses of 15 rain-forest tree species to a light gradient: the relative importance of morphological and physiological traits. Funct Ecol 13:396-410

Poorter L (2001) Light-dependent changes in biomass allocation and their importance for growth of rain forest tree species. Funct Ecol $15: 113-123$

Poorter L, Van de Plassche M, Willems S, Boot RGA (2004) Leaf traits and herbivory rates of tropical tree species differing in successional status. Plant Biol 6:1-9

Poorter H, Niinemets U, Poorter L, Wright IJ, Villar R (2009) Causes and consequences of variation in leaf mass per area (LMA): a meta-analysis. New Phytol 182:565-588

Puerta-Piñero C, Gómez JM, Zamora R (2006) Species-specific effects on topsoil development affect Quercus ilex seedling performance. Acta Oecol 29:65-71

Quero JL, Villar R, Marañon T, Zamora R (2006) Interactions of drought and shade effects on seedlings of four Quercus species: physiological and structural leaf responses. New Phytol 170:819-834 
Quero JL, Villar R, Marañon T, Zamora R, Poorter L (2007) Seed mass effects in four Mediterranean Quercus species (Fagaceae) growing in contrasting light environments. Am J Bot 94 (11):1795-1803

Quero JL, Villar R, Marañón T, Zamora R, Vega D, Sack L (2008) Relating leaf photosynthetic rate to whole-plant growth: drought and shade effects on seedlings of four Quercus species. Funct Plant Biol 35:725-737

Quero JL, Herrero A, Zamora R (2011) Linking stochasticity to determinism of woody plant recruitment in a mosaic landscape: a spatially explicit approach. Basic Appl Ecol 12:161-171

Rey Benayas JM, Navarro J, Espigares T, Nicolau JM, Zavala MA (2005) Effects of artificial shading and weed mowing in reforestation of Mediterranean abandoned cropland with contrasting Quercus species. For Ecol Manag 212:302-314

Rey Benayas JM, Fernández A, Aubenau A (2007) Clipping herbaceous vegetation improves early performance of planted seedlings of the Mediterranean shrub Quercus coccifera. Web Ecology 7:120-131

Rich PM (1989) A manual for analysis of hemispherical canopy photography. Los Alamos National Laboratory Report LA-11733-M

Ruiz-Robleto J, Villar R (2005) Relative growth rate and biomass allocation in ten woody species with different leaf longevity using phylogenetic independent contrasts (PICs). Plant Biol 7:484-494

Sack L, Grubb PJ (2002) The combined impacts of deep shade and drought on the growth and biomass allocation of shade-tolerant woody seedlings. Oecologia 131:175-185

Terradas J (2001) Hacia una nueva ecología. In: Ecología de la Vegetación. De la ecofisiología de las plantas a la dinámica de comunidades y paisaje. Ed. Omega. Barcelona, pp. 81-119

Tielbörger K, Kadmon R (2000) Temporal environmental variation tips the balance between facilitation and interference in desert plants. Ecology 81:1544-1554

Urbieta IR, Perez-Ramos IM, Zavala MA, Maranon T, Kobe RK (2008a) Soil water content and emergence time control seedling establishment in three co-occurring Mediterranean oak species.”. Can J For Res 38(9):2382-2393

Urbieta IR, Zavala MA, Marañón T (2008b) Human and non-human determinants of forest composition in southern Spain: evidence of shifts towards cork oak dominance as a result of management over the past century. J Biog 35:1688-1700

Valladares F, Guzmán B (2006) Canopy structure and spatial heterogeneity of understory light in an abandoned Holm oak Woodland. Ann For Sci 63:749-761

Valladares F, Pearcy RW (2002) Drought can be more critical in the shade than in the sun: a field study of carbon gain and photoinhibition in a Californian shrub during a dry El Niño year. Plant Cell Environ 25:749-759

Valladares F, Vilagrosa A, Peñuelas J, Ogaya R, Camarero JJ, Corcuera L, Sisó S, Gil-Pelegrin E (2008) Estrés hídrico: ecofisiología y escalas de la sequía. In: Valladares $\mathrm{F}$ (ed) Ecología del bosque mediterráneo en un mundo cambiante. Ministerio de Medio Ambiente. EGRAF, S. A, Madrid, pp 165192

Villar R, Ruiz-Robleto J, Quero JL, Poorter H, Valladares F, Marañón $T$ (2008) Tasas de crecimiento en especies leñosas: aspectos funcionales e implicaciones ecológicas. In: Valladares $\mathrm{F}(\mathrm{Ed})$. Ecología del bosque mediterráneo en un mundo cambiante. Páginas 193-230. Ministerio de Medio Ambiente, EGRAF, S. A., Madridcbrs

Villar-Salvador P, Heredia N, Millard P (2010) Remobilization of acorn nitrogen for early seedling growth in the Mediterranean oak Quercus ilex L., grown with contrasting nutrient availability. Tree Physiol 30:257-263

Wright IJ, Reich PB, Westoby M, Ackerly DD, Baruch Z, Bongers F, Cavender-Bares J, Chapin FS, Cornelissen JHC, Diemer M, Flexas J, Garnier E, Groom PK, Gulias J, Hikosaka K, Lamont BB, Lee T, Lee W, Lusk C, Midgley JJ, Navas M-L, Niinemets Ü, Oleksyn J, Osada N, Poorter H, Poot P, Prior L, Pyankov VI, Roumet C, Thomas SC, Tjoelker MG, Veneklaas EJ, Villar R (2004) The world-wide leaf economics spectrum. Nature 428:821-827

Zavala MA, Zea GE (2004) Mechanisms maintaining biodiversity in Mediterranean pine-oak forests: insights from a spatial simulation model. Plant Ecol 171:197-207

Ziegenhagen B, Kausch W (1995) Productivity of young shaded oaks (Quercus robur, L.) as corresponding to shoot morphology and leaf anatomy. For Ecol Manag 72:97-108 